\title{
A note on the changes in the preweaning growth of Pelibuey lambs
}

\author{
Una nota sobre los cambios en el crecimiento predestete de corderos Pelibuey
}

\author{
J Oliva-Hernández ${ }^{* a, ~ b}$, I del C García-Osorio ${ }^{b}$
}

\begin{abstract}
The aim of this study was to determine the influence of age of dam (AD), type of birth (TB) and age of the lamb (AL) on growth measured in terms of body weight (BW) and average daily gain (ADG) in intermediate stages between birth and weaning of the Pelibuey lambs. Twenty-two Pelibuey ewes (primiparous $=10$ and multiparous $=12)$ and their lambs $(\mathrm{n}=34)$ were used in a 2 x 2 x 5 factorial design. The factors were AD (primiparous and multiparous), TB (single and multiple) and AL (1, 10, 20, 30 and 60 days old). BW and ADG of lambs between birth and 60 days old was studied. BW and ADG were affected $(\mathrm{P}<0.05)$ by $\mathrm{TB}, \mathrm{AL}$ and the interaction TB $\times$ AL. However, BW and ADG were not affected $(\mathrm{P}>0.05)$ by $\mathrm{AD}$ and the interaction $\mathrm{AD} \times \mathrm{AL}$. In conclusion, the body weight and average daily gain of the lambs were affected by type of birth, age of lamb and type of birth $\mathrm{x}$ age of lamb.

Key words: hair sheep, lactation, preweaning performance, humid tropic.
\end{abstract}

RESUMEN. El objetivo del estudio fue determinar la influencia de la edad de la madre (EM), tipo de nacimiento (TN) y edad del cordero (EC) sobre el crecimiento medido en términos de peso vivo (PV) y ganancia diaria de peso (GDP) en etapas intermedias entre el nacimiento y el destete de los corderos Pelibuey. Se utilizaron 22 ovejas Pelibuey (primíparas $=10$ y multíparas $=12$ ) y sus corderos $(\mathrm{n}=34)$ en un diseño factorial $2 \times 2 \times 5$. Los factores fueron EM (primíparas y multíparas), TN (simple y múltiple) y EC $(1,10,2030$ y 60 días de edad). Se estudió el PV y GDP de los corderos entre el nacimiento y los 60 días de edad. El PV y GDP fueron afectados $(\mathrm{P}<0,05)$ por el TN, EC y la interacción TN x EC. Sin embargo, PV y GDP no fueron afectados $(\mathrm{P}>0,05)$ por EM y la interacción EM x EC. En conclusión, el peso vivo y ganancia diaria de peso de los corderos fueron afectados por el tipo de nacimiento, la edad del cordero y la interacción tipo de nacimiento x edad del cordero.

Palabras clave: ovejas de pelo, lactación, comportamiento predestete, trópico húmedo.

\section{INTRODUCTION}

In breeding sheep different physiological processes such as conception, gestation and lactation determine the level of productivity during their stay in a flock (Magaña-Monforte et al 2013). Particularly, the number of lambs during the lactation period is crucial, since it is during this stage where the highest mortality occurs (Nava-Lopez et al 2006, Macedo et al 2010). Additionally, it is during lactation where the lambs show higher efficiency to transform their diet, such as milk and food supplements, into live weight gain (Bell et al 1987, Souza et al 2011).

Prenatal growth and pre-weaning of hair lambs have mainly been studied based on body weight (BW), at birth and weaning, as well as the average daily gain (ADG) (Hinojosa-Cuellar et al 2009, Koritiake et al 2013). However, there is not enough information about environmental factors that affect preweaning BW and ADG that lambs show in intermediate stages between birth and

\footnotetext{
Accepted: 17.03.2016.

${ }^{a}$ Instituto Nacional de Investigaciones Forestales, Agrícolas y Pecuarias, Tabasco, México.

bUniversidad Popular de la Chontalpa, Tabasco, México.

*Corresponding author: J Oliva-Hernández; Carretera HuimanguilloCárdenas km 1, Huimanguillo, Tabasco, México, C.P. 86400; olivajh20@ yahoo.com.mx
}

weaning (Morales-Terán et al 2004, Mora-Morelos et al 2005, Pérez et al 2009). This type of knowledge could be useful to modify and/or propose strategies for feeding and handling lambs in order to optimise the productive efficiency of ewes and their litters.

The aim of the study was to determine the influence of $\mathrm{AD}, \mathrm{TB}$ and $\mathrm{AL}$ on the growth measured in terms of BW and ADG in intermediate stages between birth and weaning of Pelibuey lambs.

\section{MATERIAL AND METHODS}

The study was carried out in an experimental farm located in Huimanguillo, Tabasco (17 $7^{\circ} 50^{\prime}$ ' north latitude, $93^{\circ} 23^{\prime}$ west longitude at an altitude of 20 masl), where the climate is warm humid with rain all year (Af) and an average ambient temperature of $27.8^{\circ} \mathrm{C}$ (INEGI 2012).

Twenty-two Pelibuey ewes (primiparous $=10$ and multiparous $=12)$ and their lambs $(n=34)$ were studied in a 2 × 2 × 5 factorial design (Cody and Smith 1991). The factors were $\mathrm{AD}$ (primiparous or multiparous), $\mathrm{TB}$ (single or multiple) and $\mathrm{AL}(1,10,20,30$ and 60 days old). The experimental unit was the lamb. Primiparous and multiparous ewes had an age at lambing of $14.6 \pm 0.4$ and $40 \pm 0.7$ months, respectively. In the group multiple birth, a female that had three lambs at birth was included, however, during lactation only raised two lambs. While in the group single birth, a ewe with double lambing that raised only one lamb was included. 


\section{LAMBS MANAGEMENT}

Lambs were kept with their mothers continuously until 30 days old. During that period feed was carried out based on free access to suckling and grazing on pastures with Cynodon plectostachyus. From 30 days of age and until weaning (60 days old), lambs were subjected to a control of suckling, which was to separate them from their mothers temporarily for $11 \mathrm{~h}$ (07:00 to 18: $00 \mathrm{~h}$ ). During that period, lambs remained stabled in a pen where they had free access to water, mineral salt, hay (Arachis pintoi and C. plectostachyus) and a feed supplement of commercial type for lambs $(18 \% \mathrm{CP})$. The feed supplement was given in group during five times a day. During the night (18:00 to 7:00 h) lambs were reunited with their mothers and were allowed free access to suckling for 13 h. Lambs were weighed at birth and on days 10, 20, 30 and 60 of age. With the BW information and age ADG was determined.

\section{EWES MANAGEMENT}

Ewes were fed with a diet based on grazing and a commercial feed $(15 \% \mathrm{CP})$, the latter was given in group (300 g/ewe /d) during the lactation stage. Grazing was of the rotational type on C. plectostachyus pastures.

\section{EVALUATED VARIABLES}

The dependent variables were lamb BW at birth on days 10,20,30 and 60 of age; ADG in birth periods at day 10, day 10-20, day 20-30 and day 30-60 and weight of litter at birth (WLB) and weaning (WLW).

\section{STATISTICAL ANALYSIS}

All statistical analyses were conducted using the computer program SAS (SAS 2000). The MIXED procedure was used for the analysis of BW and ADG using a linear mixed model for repeated measures. As a random factor the ewe was included in the model. In the final statistical model the interactions $\mathrm{AD} \times \mathrm{TB}, \mathrm{AD} \times \mathrm{AL}$ and $\mathrm{AD} \times \mathrm{TB}$ $x$ AL were excluded because in a previous analysis it was not significant $(P>0.05)$. Least square means were calculated and separated using the PDIFF option. Values of least square means were considered statistically significant when $\mathrm{P}<0.05$. The TTEST procedure was used to determine confidence interval for each pair of means whereas the studied factors that had significant difference $(\mathrm{P}<0.05)(\mathrm{TB}, \mathrm{AL}$ and interaction $\mathrm{TB} \times \mathrm{AL})$.

In the analysis of WLB and WLW a model considering $\mathrm{AD}$ and $\mathrm{TB}$ factors was used, interaction $\mathrm{AD} \times \mathrm{TB}$ was excluded because in a previous analysis was not significant $(\mathrm{P}>0.05)$. The experimental unit was the litter. Statistical analysis of data was performed using the GLM procedure.

\section{RESULTS AND DISCUSSION}

The analyses of variance for BW and ADG are presented in table 1. Type of birth, AL and the interaction TB $x$ $\mathrm{AL}$ affected $\mathrm{BW}$ and $\mathrm{ADG}(\mathrm{P}<0.05)$. AD and the rest of interactions did not affect $\mathrm{BW}$ and $\mathrm{ADG}(\mathrm{P}>0.05)$. Single lambs had a higher BW $(\mathrm{P}<0.05)$ than those of multiple births (table 2). These results are similar to those reported by Carrillo et al (1987) and González et al (2002) where the BW of Pelibuey and Blackbelly twin lambs weaned at 90 days is lower than that in single lambs and it represents 92 and $85 \%$ of BW, respectively. However, in previous studies with Pelibuey lambs (Macias-Cruz et al 2009, HinojosaCuéllar et al 2012) difference in BW at weaning between single and twin lambs has not been detected.

Body weight increased $(\mathrm{P}<0.05)$ along with age (table 2). BW steady increase in lambs was attributed to the fact that they fed on mother's milk, and on a feed supplement during the second month of life. In agreement with the previously aforesaid, Morales-Terán et al (2004) indicate that BW of Pelibuey lambs (with continuous suckling) from multiparous ewes is affected by lamb age, detecting an increase in the lamb BW (determined at intervals of seven days from birth and up to 63 days of age) of similar magnitude to that registered in the present study.

The least squares means $\pm \mathrm{SE}$ and confidence intervals (95\%) for BW considering TB and AL are presented in tables 3 and 4. Single lambs showed to be higher in BW from 10 days old in relation to multiple lambs, this advantage was $34 \%$ at 60 days of age. This result agrees with various studies on Pelibuey lambs reporting that single lambs show $8 \%$ more in BW at weaning than twin lambs (Carrillo et al 1987). In this regard, postnatal growth is limited by the level of maternal nutrition and other environmental factors that affect milk production (Bell et al 1987, Alexandre et al 2001, Martínez-González et al 2015). In this study, both types of ewes (single and multiple lambing) had a similar nutritional management during lactation, a situation that probably puts in disadvantage the ewes with two lambs, since nutrient needs in this type of ewes are higher (NRC 2007), a fact that may have adversely affected the level of milk production, individual consumption of milk and lamb BW.

Average daily gain was higher $(\mathrm{P}<0.05)$ in single lambs than in those of multiple type of birth (table 2). Registered values in the ADG preweaning of lambs are higher than those indicated in Pelibuey lambs (93 g) with restricted suckling during the day and continuous during the night (Ríos-Utrera et al 2014). However, they are within those values registered in Pelibuey lambs (141-156 g) handled in lactations of 60 days with access to grazing in the first 15 days of life followed by restricted suckling and stabling until weaning (Hinojosa-Cuéllar et al 2013). Divergences in ADG reported between studies could be attributed to differences in the control of lamb lactation and in the feeding program of ewes and lambs. 
Table 1. Analysis of variance of body weights (BW) and preweaning average daily gain (ADG) of Pelibuey lambs.

Análisis de varianza de la variable peso y ganancias diarias de peso predestete de corderos Pelibuey.

\begin{tabular}{lcccccc}
\hline \multirow{2}{*}{ Source of variation } & \multicolumn{3}{c}{$\mathrm{BW}$} & & \multicolumn{3}{c}{ ADG } \\
\cline { 2 - 3 } \cline { 5 - 6 } \cline { 5 - 6 } & $\mathrm{df}$ & $\mathrm{F}$ & & $\mathrm{df}$ & $\mathrm{F}$ \\
\hline Age of dam (AD) & 1 & $\mathrm{~ns}$ & & 1 & $\mathrm{~ns}$ \\
Type of birth (TB) & 1 & $*$ & & 1 & $*$ \\
Age of lamb (AL) & 4 & $*$ & & 3 & $*$ \\
TBxAL & 4 & $*$ & & 3 & $*$ \\
Error & 11 & & & 13 & \\
Total corrected & 21 & & & 21 & \\
\hline
\end{tabular}

$\mathrm{df}=$ degree of freedom; $\mathrm{ns}=\mathrm{P}>0.05 ; * \mathrm{P}<0.05$.

$\mathrm{gl}=$ grados de libertad; $\mathrm{ns}=\mathrm{P}>0,05 ; * \mathrm{P}<0,05$.

Table 2. Least square means \pm standard error for weight and average daily gain by type of birth and age of Pelibuey lambs

Medias de cuadrados mínimos \pm error estándar para peso vivo y ganancia diaria de peso por tipo de nacimiento y edad de corderos Pelibuey.

\begin{tabular}{|c|c|c|c|}
\hline Effect & $\mathrm{n}$ & $\begin{array}{l}\text { Body weight } \\
(\mathrm{kg})\end{array}$ & $\begin{array}{l}\text { Average daily } \\
\text { gain }(\mathrm{g})\end{array}$ \\
\hline \multicolumn{4}{|l|}{ Type of birth } \\
\hline Single & 9 & $\begin{array}{c}7.3^{\mathrm{a}} \pm 0.31 \\
(6.2-8.5)\end{array}$ & $\begin{array}{l}175^{\mathrm{a}} \pm 10 \\
(154-197)\end{array}$ \\
\hline Multiple & 13 & $\begin{array}{c}5.3^{b} \pm 0.25 \\
(4.8-5.8)\end{array}$ & $\begin{array}{c}130^{\mathrm{b}} \pm 7 \\
(119-140)\end{array}$ \\
\hline \multicolumn{4}{|c|}{ Age of lamb (days) } \\
\hline 1 & 22 & $\begin{array}{c}2.6^{\mathrm{a}} \pm 0.25 \\
(2.2-2.6)\end{array}$ & \\
\hline 10 & 22 & $\begin{array}{c}4.3^{\mathrm{b}} \pm 0.25 \\
(3.7-4.3)\end{array}$ & $\begin{array}{l}175^{\mathrm{a}} \pm 11 \\
(146-186)\end{array}$ \\
\hline 20 & 22 & $\begin{array}{c}5.9^{c} \pm 0.25 \\
(4.9-5.8)\end{array}$ & $\begin{array}{l}158^{\mathrm{a}} \pm 11 \\
(110-158)\end{array}$ \\
\hline 30 & 22 & $\begin{array}{c}7.1^{\mathrm{d}} \pm 0.25 \\
(6.0-7.1)\end{array}$ & $\begin{array}{c}125^{\mathrm{b}} \pm 11 \\
(104-138)\end{array}$ \\
\hline 60 & 22 & $\begin{array}{c}11.7^{\mathrm{e}} \pm 0.25 \\
(10.0-11.7)\end{array}$ & $\begin{array}{l}153^{\mathrm{ab}_{ \pm}} 11 \\
(126-162)\end{array}$ \\
\hline
\end{tabular}

$\mathrm{a}, \mathrm{b}, \mathrm{c}, \mathrm{d}, \mathrm{e}$, least squares means $\pm \mathrm{SE}$ within of column and same effect with different superscript letters are significantly different $(\mathrm{P}<0.05)$; values between parenthesis $=$ confidence interval $(95 \%)$.

a, b, c, d, e, medias de cuadrados mínimos $\pm \mathrm{EE}$ con diferente superíndice dentro de la misma columna y similar efecto indican diferencia significativa $(\mathrm{P}<0,05)$; valores entre paréntesis $=$ intervalo de confianza $(95 \%)$.

Average daily gain of lambs was higher $(\mathrm{P}<0.05)$ between birth and 20 days of age when compared to that registered between 20 and 30 days of age (table 2). In previous studies (Morales-Terán et al 2004, Pérez et al 2009, Martínez-González et al 2015) the ADG of Pelibuey lambs (with continuous suckling) is described at different intervals
Table 3. Effect of type of birth and age of the lamb on preweaning body weight of Pelibuey lambs.

Influencia del tipo de nacimiento y edad sobre el peso vivo predestete de corderos Pelibuey.

\begin{tabular}{|c|c|c|}
\hline \multirow{2}{*}{ Age of the lamb (days) } & \multicolumn{2}{|c|}{ Type of birth } \\
\hline & Single & Multiple \\
\hline 1 & $3.0^{\mathrm{a} A} \pm 0.41$ & $2.1^{\mathrm{a} \mathrm{A}} \pm 0.29$ \\
\hline 10 & $4.9^{\mathrm{a} B} \pm 0.41$ & $3.7^{\mathrm{b} B} \pm 0.29$ \\
\hline 20 & $7.0^{\mathrm{aC}} \pm 0.41$ & $4.8^{\mathrm{bC}} \pm 0.29$ \\
\hline 30 & $8.3^{\mathrm{a} D} \pm 0.41$ & $6.0^{\mathrm{b} \mathrm{D}} \pm 0.29$ \\
\hline 60 & $13.4^{\mathrm{a} \mathrm{E}} \pm 0.41$ & $10.0^{\mathrm{b} E} \pm 0.29$ \\
\hline
\end{tabular}

Number of observations

9

26

$\mathrm{a}$, b, least squares means $\pm \mathrm{SE}$ in the same row with different superscript letters are significantly different $(\mathrm{P}<0.05)$.

$\mathrm{A}, \mathrm{B}, \mathrm{C}, \mathrm{D}, \mathrm{E}$, least squares means $\pm \mathrm{SE}$ in the same column with different superscript letters are significantly different $(\mathrm{P}<0.05)$.

$\mathrm{a}, \mathrm{b}$, medias de cuadrados mínimos $\pm \mathrm{EE}$ con diferente superíndice dentro de la misma fila indican diferencia significativa $(\mathrm{P}<0,05)$.

A, B , C, D, E, medias de cuadrados mínimos \pm EE con diferente superíndice dentro de la misma columna indican diferencia significativa $(\mathrm{P}<0,05)$.

of lactation, without having specified the influence of the lamb age on ADG. For example, Perez et al (2009) showed that lamb ADG is gradually reduced from $202 \mathrm{~g}$ (on day seven of age) to $156 \mathrm{~g}$ (on day 56), while Morales-Terán et al (2004) describe that lamb ADG is of 150 at seven days of age, increasing to $200 \mathrm{~g}$ (approximately) at 14 days and without showing wide variations until day 56 of age. The results of this study partially agree with the trend in the ADG decrease as lactation advances described by Perez et al (2009). It is possible that reduction in ADG during the first month of lamb life is attributed to a decrease in milk production of ewes (Castellanos and Valencia 1982, Snowder and Glimp, 1991). However, in the second month of lamb life, ADG was similar with respect to that detected in the first 20 days old. It is likely that this response is attributed to the lambs achieved a higher consumption of feed supplement in the last weeks of lactation when compared to the first weeks, a situation that could offset the decline in milk production ewe (Godfrey et al 1997).

The least squares means $\pm \mathrm{SE}$ and confidence intervals (95\%) for lamb ADG considering TB and AL are presented in table 4 and figure 1 . ADG of single lambs was higher $(\mathrm{P}<0.05)$ than that of multiple lambs between days 10 and 20 of age. The reason for this advantage might be that ewes were in the plateau of their milk production (Castellanos and Valencia 1982, Ferreira et al 2011) and to the absence of competition for access to the two mammary glands (Snowder and Glimp 1991).

Between 20 and 30 days of age, single lambs showed a reduction in ADG, which was not presented in multiple lambs. This result agrees with that indicated by Mora-Morelos et al (2005) who detected a lower ADG of Pelibuey lambs of single birth on day 39 compared to day 11 of age. It is possible that the ADG reduction in single lambs is related to a decrease in the level of 
Table 4. Confidence interval (95\%) for body weight (BW) and average daily gain (ADG) by type of birth and age of Pelibuey lambs.

Intervalo de confianza para peso corporal y ganancia promedio diaria según tipo de nacimiento y edad de corderos Pelibuey.

\begin{tabular}{lcccc}
\hline \multirow{2}{*}{$\begin{array}{l}\text { Age of the } \\
\text { lamb (days) }\end{array}$} & \multicolumn{4}{c}{ Type of birth } \\
\cline { 2 - 5 } & \multicolumn{2}{c}{ Single } & \multicolumn{2}{c}{ Multiple } \\
\cline { 2 - 5 } & BW (kg) & ADG (g) & BW (kg) & ADG (g) \\
\hline 1 & $2.5-3.5$ & & $2.0-2.3$ \\
10 & $4.2-5.6$ & $155-231$ & $3.5-4.0$ & $133-180$ \\
20 & $5.9-8.0$ & $137-275$ & $4.5-5.1$ & $93-126$ \\
30 & $7.0-9.6$ & $88-179$ & $5.6-6.4$ & $97-136$ \\
60 & $12.1-14.7$ & $154-186$ & $9.2-10.8$ & $112-158$ \\
\hline
\end{tabular}

milk production of ewes at this stage (20 to 30 days) and/or that the amount of milk consumed by the lamb is not enough to meet the growing demand for nutriments required by the growth process (Owens et al 1993, NRC 2007). Additionally, Castellanos and Valencia (1982) indicated that in the Pelibuey ewe milk production is reduced from the third week of lactation and that this decline is greater at the end of the second month after lambing. Additionally, it is important to consider that lambs are fed milk ad libitum, and consumption of a feed supplement is low compared to lambs with restricted access to milk (Ørskov 1988). In this sense, it is likely that single lambs achieve a higher consumption of milk in the first weeks with regard to multiple lambs (for having access to the two mammary glands), a situation that could delay the consumption of solid feed and development of the rumen-reticulum.

In multiple lambs, the ADG reduction is presented from 10 days of age and remained unchanged until day 60 of age. In these lambs, a peak in the ADG was not detected probably by the level of competition for access to the mammary glands. In previous studies it has been documented that milk production in a ewe nursing twin lambs can be greater (Alexandre et al 2001, Jawasreh and Khasawneh 2007) or similar (Godfrey et al 1997) than milk production in ewes nursing single lambs. Nonetheless, the amount of milk produced by an ewe with two lambs or more has to be shared among the offspring, a situation that could limit the intake of nutriments provided by milk.

The age of dam did not affect WLB ( $P>0.05)$, a finding partially consistent as described in Blackbelly ewes (Cadenas-Cruz et al 2012). In this latest study ewes in their first and second lambing showed a similar WLB, but lower than that of ewes with more than two lambings. In a previous study done with Pelibuey and Blackbelly ewes indicates that WLB was similar during the first three lambings, but in subsequent lambings it is increased (Segura et al 1996). Differences among studies probably are associated with the type of nutritional management applied to ewes during pregnancy and the degree of precision to establish the number of lambing of the ewes.

The age of dam did not affect the WLW (P > 0.05), a similar result is reported for hair sheep in their first four lambings (Hinojosa-Cuellar et al 2015). However, it differs from previous studies on Blackbelly (Cadenas-Cruz et al 2012) and Pelibuey ewes (Magaña-Monforte et al 2013)

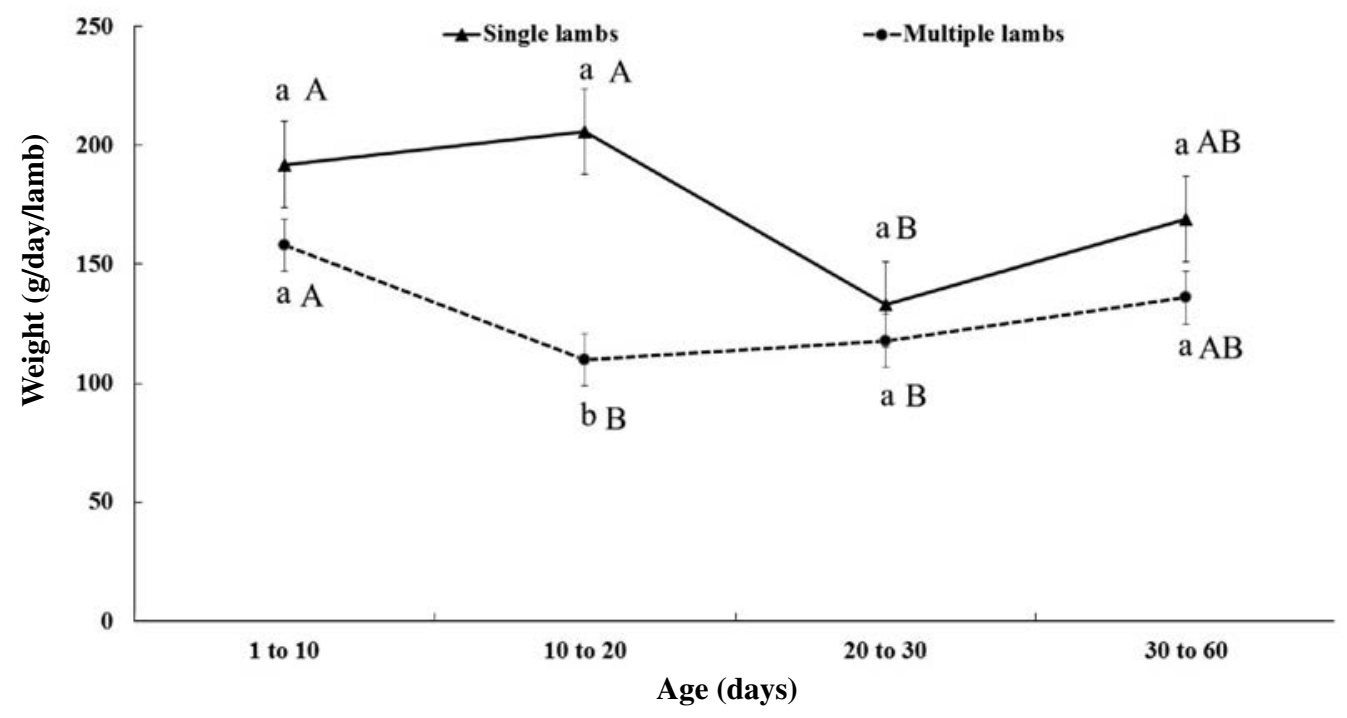

Figure 1. Effect of type of birth and age of the lamb on preweaning daily weight gain of the Pelibuey lamb. a, b, least squares mean $\pm \mathrm{SE}$ between lines with different superscript letters are significantly different $(\mathrm{P}<0.05)$. A, B, least squares mean $\pm \mathrm{SE}$ in the same line with different superscript letters are significantly different $(\mathrm{P}<0.05)$.

Influencia del tipo de nacimiento y edad del cordero sobre la ganancia diaria de peso predestete del cordero Pelibuey. a, b, medias de cuadrados mínimos $\pm \mathrm{EE}$ con diferente superíndice entre líneas indican diferencia significativa $(\mathrm{P}<0,05)$. A, B, medias de cuadrados mínimos \pm EE con diferente superíndice dentro de la misma línea indican diferencia significativa $(\mathrm{P}<0,05)$. 
Table 5. Least square means \pm standard error for weight of litter by type of birth of Pelibuey lamb.

Medias de cuadrados mínimos \pm error estándar para peso de la camada por tipo de nacimiento del cordero Pelibuey.

\begin{tabular}{lccc}
\hline & $\mathrm{n}$ & $\begin{array}{c}\text { Weight of litter at } \\
\text { birth }(\mathrm{kg})\end{array}$ & $\begin{array}{c}\text { Weight of litter at } \\
\text { weaning }(\mathrm{kg})\end{array}$ \\
\hline Single & 9 & $3.0^{\mathrm{a}} \pm 0.26$ & $13.3^{\mathrm{a}} \pm 1.38$ \\
& & $(2.5-3.5)$ & $(12.1-14.7)$ \\
Multiple & 13 & $\begin{array}{c}4.4^{\mathrm{b}} \pm 0.22 \\
(3.9-4.9)\end{array}$ & $\begin{array}{c}20.0^{\mathrm{b}} \pm 0.77 \\
\end{array}$ \\
& & $(18.1-21.9)$ \\
\hline
\end{tabular}

$\mathrm{a}, \mathrm{b}$, least squares means $\pm \mathrm{SE}$ in the same column with different superscript letters are significantly different $(\mathrm{P}<0.05)$; values between parenthesis $=$ confidence interval $(95 \%)$.

a, b, medias de cuadrados mínimos \pm EE con diferente superíndice dentro de la misma columna indican diferencia significativa $(\mathrm{P}<0,05)$; valores entre paréntesis= intervalo de confianza $(95 \%)$.

where it is shown that ewes with more than two lambings have greater capacity to produce heavier litters at weaning than those of first lambing. The preweaning growth of litter is influenced by nutritional management applied to the ewe and its litter as well as environmental factors (Bell et al 1987, Koritiaki et al 2012, 2013). Discrepancies between studies are probably related to differences in age at weaning, nutritional management and housing conditions.

Single litters showed lower weight $(\mathrm{P}<0.05)$ at birth and at 60 days when compared to multiple litters (table 5), which is consistent with the weight reported for hair sheep (Magaña-Monforte et al 2013, Hinojosa-Cuellar et al 2015).

In conclusion, under the conditions of this study, the interaction between type of birth and age of lamb affected preweaning daily weight gain of Pelibuey lambs. The greater weight gain occurred in the first 20 days of age. Single lambs showed a higher ADG in the first lambed days with respect to multiple lambs; this advantage enables them to achieve a higher body weight at 60 days of age. In multiple lambs average daily gain is reduced until day 30 of age and then increases.

\section{REFERENCES}

Alexandre G, H Archimède, E Chevaux, G Aumont, A Xandé. 2001. Feeding supply of suckling Martinik ewes reared in intensive conditions: effects of supplement levels and litter size. Anim Res 50, 213-221.

Bell AW, DE Bauman, WB Currie. 1987. Regulation of nutrient partitioning and metabolism during pre- and postnatal growth. $J$ Anim Sci 65 (Suppl. 2), 186-212.

Cadenas-Cruz PJ, J Oliva-Hernández, JA Hinojosa-Cuéllar. 2012. Productivity of Blackbelly ewes and their hybrid litter under grazing. J Anim Vet Adv 11, 97-102.

Carrillo AL, A Velásquez, T Ornelas. 1987. Algunos factores ambientales que afectan el peso al nacer y al destete de corderos Pelibuey. Téc Реси Мéx 25, 289-295.

Castellanos A, M Valencia. 1982. Estudio cuantitativo y cualitativo de la producción láctea de la borrega Pelibuey. Prod Anim Trop 7, 245-255.

Cody RP, JK Smith. 1991. Applied statistics and the SAS programming language. $3^{\text {rd }}$ ed. Elsevier Science Publishing Company Inc., New York, USA, Pp 163-202.
Ferreira MIC, I Borges, GL Macedo Junior, NM Rodriguez, CFAM Penna, MR Souza, MGT Gomes, FA Souza, LF Cavalcanti. 2011. Produção e composição do leite de ovelhas Santa Inês e mestiças Lacaune e Santa Inês e desenvolvimento de seus cordeiros. Arq Bras Med Vet Zootec 63, 530-533.

González GR, G Torres, MA Castillo. 2002. Crecimiento de corderos Blackbelly entre el nacimiento y el peso final en el trópico húmedo de México. Vet Méx 33, 443-453.

Godfrey RW, LM Gray, JR Collins. 1997. Lamb growth and milk production of hair and wool sheep in a semi-arid tropical environment. Small Rumin Res 24, 77-83.

Hinojosa-Cuéllar JA, F de M Regalado-Arrázola, J Oliva-Hernández. 2009. Crecimiento prenatal y predestete en corderos Pelibuey, Dorper, Katahdin y sus cruces en el Sureste de México. Rev Cient FCV-LUZ 19, 522-532.

Hinojosa-Cuéllar JA, J Oliva-Hernández, G Torres-Hernández, JC Segura-Correa, EM Aranda-Ibáñez, JM González-Camacho JM. 2012. Factores que afectan el crecimiento predestete de corderos Pelibuey en el trópico húmedo de México. Univ Cienc 28, 163-171.

Hinojosa-Cuéllar JA, J Oliva-Hernández, G Torres-Hernández, JC Segura-Correa. 2013. Comportamiento productivo de corderos $\mathrm{F}_{1}$ Pelibuey x Blackbelly y cruces con Dorper y Katahdin en un sistema de producción del trópico húmedo de Tabasco, México. Arch Med Vet 45, 135-143.

Hinojosa-Cuéllar JA, J Oliva-Hernández, G Torres-Hernández, JC Segura-Correa, R González-Garduño. 2015. Productividad de ovejas $F_{1}$ Pelibuey x Blackbelly y sus cruces con Dorper y Katahdin en un sistema de producción del trópico húmedo de Tabasco, México. Arch Med Vet 47, 167-174.

INEGI, Instituto Nacional de Estadística y Geografía. 2012. Anuario Estadístico. Tabasco, México.

Jawasreh KIZ, AZ Khasawneh. 2007. Genetic evaluation of milk production traits in awassi sheep in Jordan. Egyptian J Sheep Goat Sci 21, 83-100.

Koritiake NA, ELA Ribeiro, DC Scerbo, IY Mizubuti, LDF Silva, MAAF Barbosa, CL Souza, FHP Paiva. 2012. Fatores que afetam o desempenho de cordeiros Santa Inês puros e cruzados do nascimento ao desmame. Rev Bras Saúde Prod Anim 13, 258-270.

Koritiake, NA, ELA Ribeiro, IY Mizubuti, LDF Silva, MAAF Barbosa, DC Scerbo, CASD Muniz, F Fernandes Júnior. 2013. Effect of environmental factors on performance of purebred and crossbred Santa Inês lambs from birth to 154 days of age. $R$ Bras Zootec 42, 87-94.

Macedo R, V Arredondo, J Rodríguez, J Ramírez, B López. 2010. Efecto del sistema de producción, de la época de nacimiento y del sexo sobre la mortalidad neonatal de corderos Pelibuey. Trop Subtrop Agroecosyt 12, 77-84.

Macías-Cruz U, FD Álvarez-Valenzuela, A Correa-Calderón, L MolinaRamírez, A Gónzalez-Reyna, S Soto-Navarro, L Avendaño-Reyes. 2009. Pelibuey ewe productivity and subsequent pre-weaning lamb performance using hair-sheep breeds under a confinement system. J Appl Anim Res 36, 255-260.

Magaña-Monforte JG, M Huchin-Cab, RJ Ake-López, JC Segura-Correa. 2013. A field study of reproductive performance and productivity of Pelibuey ewes in Southeastern Mexico. Trop Anim Health Prod 45, 1771-1776.

Martínez-González S, F Escalera-Valente, AA Gómez-Dánes, A Plascencia, JL Loya-Olguin, JC Ramírez-Ramírez, A Barreras, YS Valdés-García, J Aguirre-Ortega. 2015. Influence of levels of DL-malic acid supplementation on milk production and composition in lactating Pelibuey ewes and pre-weaning weight gain of their suckling kids. J Appl Anim Res 43, 92-96.

Morales-Terán G, A Pro-Martínez A, B Figueroa-Sandoval B, C Sánchezdel-Real C, J Gallegos-Sánchez. 2004. Amamantamiento continuo o restringido y su relación con la duración del anestro postparto en ovejas Pelibuey. Agrociencia 38, 165-171.

Mora-Morelos H, JA Hinojosa-Cuéllar, J Oliva-Hernández. 2005. Ganancia de peso de los corderos Pelibuey en pastoreo y complemento alimenticio. Tecnociencia Universitaria 4, 20-30. 
Nava-López VM, J Oliva-Hernández, JA Hinojosa-Cuéllar. 2006. Mortalidad de los ovinos de pelo en tres épocas climáticas en un rebaño comercial en la Chontalpa, Tabasco, México. Univ Cienc 22, 119-129.

NRC, National Research Council. 2007. Nutrient requirements of small ruminants. Sheep, goats, cervids, and new world camelids. The National Academies Press, Washington, DC, USA, Pp 54-60.

Ørskov ER. 1988. Nutrición proteica de los rumiantes. $1^{\mathrm{ra}}$ ed. Acribia SA, Zaragoza, España, Pp 15-17.

Owens FN, P Dubeski, CF Hanson. 1993. Factors that alter the growth and development of ruminants. J Anim Sci 71, 3138-3150.

Pérez P, VVM Hernández, SB Figueroa, G Torres, RP Díaz, J Gallegos. 2009. Efecto del tipo de amamantamiento en la actividad ovárica posparto de ovejas Pelibuey y tasas de crecimiento de corderos en los primeros 90 días de edad. Rev Cient FCV LUZ 19, 343-349.
Ríos-Utrera A, R Calderón-Robles, J Lagunes-Lagunes, J Oliva-Hernández. 2014. Ganancia de peso predestete en corderos Pelibuey y sus cruces con Blackbelly, Dorper y Katahdin. Nova Scientia 6, 272-286.

SAS. 2000. Statistical Analysis System. User's. Guide. Statistics Institute Inc., Cary, NC, USA.

Segura JC, L Sarmiento, O Rojas. 1996. Productivity of Pelibuey and Blackbelly ewes in México under extensive management. Small Rumin Res 21, 57-62.

Snowder GD, HA Glimp. 1991. Influence of bree, number of suckling lambs, and stage of lactating on ewe milk production and lamb growth under range conditions. J Anim Sci 69, 923-930.

Souza LA, PLZ Carneiro, CEM Malhado, SR Paiva, DN Caires, DLF Barreto. 2011. Curvas de crescimento em ovinos raça morada nova criados no estado da Bahia. R Bras Zootec 40, 1700-1705. 